\title{
Characteristics Of Underrepresented Self-Employed Groups
}

Andrea E. Smith-Hunter, Siena College

\begin{abstract}
This paper covers concerns of self-employed individuals by looking at specific issues that are related to underrepresented sectors in the study area: women, racial minorities of both genders, and women in racial minority groups. It is necessary to focus on these areas due to their underrepresentation in thinly research areas, with not many empirical issues or statistical findings being addressed in these areas. This paper is mainly theoretical, and answers two critical questions: (1) What are the distinct characteristics of underrepresented self-employed groups compared to the dominant group - white males? (2) What are the key explanations and reasons for these groups having such characteristics? Trends in self-employment over the last six decades are examined, as well as the distinct characteristics of self-employed women, minorities, and minority women.
\end{abstract}

Keywords: Self-employment, minorities, entrepreneurship

\section{INTRODUCTION}

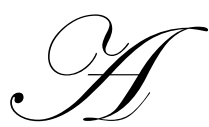

ccording to Yamada (1996), at least one out of every five members of the urban labor force in developing countries is self-employed. Such a large representation qualifies the self-employment sector as a major area of study, considering the significant increases in the research focus and in the quantitative numbers of the labor force who occupy this area, especially in the last two decades (Marlow and Patton, 2005; Kuhn and Schuetze, 2001; Hundley, 2000, Boden, 1999a; Boden, 1999b; Zapalske, 1997). In spite of the recent focus, there is not a lot of comprehensive empirical or theoretical work available on the topic. What does exist, is limited to predictable topics that mainly revisit areas of entrepreneurship explored by other factions, in topics such as the focus on the personal traits that make a self-employed individual successful (Marlow and Patton, 2005; Caputo and Dolinsky, 1998), or the often-repeated focus of the differences between males and females (Boden, 1999b; Kuhn and Schuetze, 2001).

Underrepresented sectors in the study area are: women, racial minorities of both genders, and women from racial minority backgrounds. These underrepresented sectors are thinly researched, with few empirical issues or statistical findings addressed.

Two critical questions are addressed in this paper: (1) What are the distinct characteristics of underrepresented self-employed groups compared to the dominant group - white males? and, (2) What are the key explanations and reasons for these groups having such characteristics? Women, racial minorities of both genders, and minority women have long occupied less favorable positions in the mainstream labor market. Current research in this area indicates that their positions are no more favorable in the self-employment sector. Since the onset of the Civil Rights Movement of the 1950s and 1960s and the Feminist Movement of the 1960s and 1970s, the racial gender composition of employed individuals has changed dramatically. Women, minorities, and minority women are entering nontraditional areas such as self-employment in record numbers, especially in recent years. 


\section{DEFINITIONS AND CLARIFICATIONS}

A self-employed individual is literally and simply defined as someone who works for themself or who is employed by oneself (Steinmetz and Wright, 1989). Self-employment is related to entrepreneurship and entrepreneurs, who are defined as individual who perceive an opportunity and partake in the necessary functions, activities and actions associated with the creation of an organization to pursue an opportunity (Bygrave and Hofer, 1991; Gartner, 1988; Sexton and Smilor, 1986).

Additional definitions and clarifications in this paper are related to issues of race and to what have been referred to in this context as minorities and minority women.

"White" refers to individuals not of Hispanic origins, whose ancestry and roots relate to any of the original peoples of Europe, North Africa, or the Middle East. (Smith, 1998)

"Black" refers to persons having origins in any of the Black racial groups of Africa, including individuals from the Caribbean or West Indian countries who currently reside in the United States (Smith, 1998). The terms "Black" and "African American" are used interchangeably.

"Hispanic/Latino" refers to persons of Mexican, Puerto Rican, Cuban, Central or South American, or other Spanish culture or origin.

"Asian or Pacific Islander," includes persons having origins in any of the original peoples of the Far East, Southeast Asia, the Indian subcontinent, or the pacific Islands, including China, Japan, Korea, India, Pakistan, Nepal, the Phillipine Islands, Somoa, and Polynesia. (Smith, 1998)

These definitions are used on the United States Census Bureau website and by the United States Bureau of Labor Statistics, whose data can be found in the tables referenced throughout this paper.

In this paper, "Minority women" refers to women who are not classified as White, that is, women in the following categories: Black, Hispanic and Asian.

\section{TRENDS IN SELF-EMPLOYED UNDERREPRESENTED GROUPS}

Data on self-employment in the United States is regularly collected as part of the monthly Current Population Survey (CPS) of the United States Labor Force (Bregger, 1996). The survey was originally used to determine how many people were employed at a time when the United States was still suffering the effects of the Great Depression of the 1930s. The CPS categorizes different classes of workers based on a number of characteristics and places. The most recent self-employment figures are provided by the United States Bureau of Labor Statistics, Table 16, entitled Employed and Unemployed Full and Part-Time Workers by Class of Worker, Sex, Race and Hispanic and Latino Ethnicity (Annual Average-2006). This table is still available through the Current Population Survey, and provides details on all workers in agriculture and nonagriculture industries, including self-employed workers.

Current figures from CPS indicate that the number of self-employed persons in 2006 was less than in 1995, as well as the 1940s (Bregger, 1996; United States Department of Labor Statistics, 2006). The percentage of selfemployed individuals among all employed individuals declined from 18.5 percent in 1948 to 11.1 percent in 1966, and to 8.9 percent in 1970 (Bregger, 1996). Self-employment figures remained at approximately 8.7 percent in the 1970s through the 1990s (Bregger, 1996). More recent figures show increases to 8.8 percent in 1995 (Bregger, 1996) and 13.82 percent in 2006, see also Table 1.

The percentage of self-employed women in the nonagricultural sector increased from 4.1 percent in 1975 to 6.7 percent in 1990 to 7.85 percent in 2006, see also Table 1 (Bregger, 1996; Steinmetz and Wright, 1989). The figures for men, on the other hand, were at 10.1 percent in 1975, 12.4 percent in 1990, and 13.01 percent in 2006, 
see also Table 1 (Devine, 1994). The percentage of women, as compared to the total number of self-employed individuals, increased dramatically in the last few decades (Blau, 1987).

According to a previous study by the National Foundation of Women Business Owners (NFWBO), the number of self-employed women was close to one third of the total self-employed individuals (Brown, 1996). By 2000, they predicted, half of all self-employed individuals would be women, with African American, Asian, and Latino women making up the largest and fastest growing segment of this sector (Brown, 2006). These predictions did not hold true according to Brown (1996), since figures from 2006 show White women holding at 87.1 percent, resulting in a minor percentage (12.9) being occupied by minority women, as shown in Tables 2, 3, and 4

The number of self-employed Blacks has increased over the last few decades, and increased by 23.3 percent between 1975 and 1985 (Sullivan and McCracken, 1988). Later figures place the percentage of selfemployed Blacks as compared to the total number of self-employed individuals in 1990 at 11.9 percent (Devine, 1994). The percentage of self-employed Blacks among all self-employed individuals moved from 6.6 percent in 1975 to 8.1 percent in 1990 and decreased to 5.61 percent in 2006, as shown in Table 2 (Devine, 1994; United States Department of labor Statistics, 2006). Historical statistical figures on Black women are not abundantly available, however the percentage of self-employed Black women increased slightly from 3.8 percent in 1975 to 3.9 percent in 1990, and then decreased to 2.09 percent in 2006, as a percentage of total self-employed individuals, as shown in Table 2 (Devine, 1994).

The figures for other underrepresented groups show that the number of Asians and Hispanics as a percentage of all self-employed individuals stands at 4.75 percent and 9.18 percent respectively as shown in Tables 3 and 4, and the percentage of Asian and Hispanic women among all self-employed individuals is 2.00 percent and 3.02 percent respectively, as shown in Tables 3 and 4 .

Many factors have contributed to the changes in the self-employment sector over the last four decadesparticularly for the underrepresented groups. For example, fewer Blacks are employed in the agricultural sector compared to five decades ago, and are now employed more in retail and service industries (Bregger, 1963; Jones, 1994; Smith-Hunter, 2006). Other minorities have also embraced state and federal jobs as they have become more educated (Smith-Hunter, 2006). Reasons for such shifts can be consolidated and reduced to a common denominator: the decline in the number of small farms in favor of larger farm operations (Woodson, 1988). Forcing the previously employed in such areas to seek employment elsewhere.

In contrast, more recent changes in capital available for start-ups, and other network services, have increased the opportunities available to underrepresented groups in both the self-employment sector and mainstream labor market (Bates, 1991). Blacks of both genders, women of all races, and Black women now have more employment opportunities and government program assistance for start-ups and continuation of self-employed enterprises (Allen and Truman, 1993; Brown, 1996; Horton, 1988; Marlow and Patton, 2005). Blocked opportunities in the workplace and the glass ceiling effect have resulted in underrepresented groups seeking self-employment as an alternative to other traditional employment (Bell, 1990; England and McCrackep, 1987; Collins, 1993; SmithHunter. 2006).

The overall increase in self-employment figures in more recent years can be attributed to six main factors. According to Bregger (1963), Blau (1987), Bates (1995), and Steinmetz and Wright (1989). The labor market has historically favored industries in which small firms are viable but scale economies (large scale operations) are relatively unimportant (Bates, 1995). Relative prices have shifted in favor of industries in which self-employment is relatively common, creating growth in such industries (Bregger, 1963). Rising marginal tax rates have made selfemployment more attractive, because of the ease of underreporting income from self-employment, compared to that of wage-salary earnings (Bates, 1995). Increased wage rigidity has increased the proportion of the labor force that resorts to self-employment as a response to being rationed out of wage jobs (Steinmetz and Wright, 1989). Rising real retirement benefit levels under the Old Age Security and Disability Insurance (OASDI) program, as well as greater flexibility in hours worked, has increased the rate at which older workers shift from wage-salary to self- 
employment (Blau, 1987). In addition, changes in technology, such as the proliferation of personal computers, have made small firms more competitive in many industries (Steinmetz and Wright).

Theorists who analyze contemporary social trends argue that the recent rise in self-employment might be part of a qualitatively new phase of economic development (Steinmetz and Wright, 1989; Kuhn and Schuetze, 2001; United States Bureau of Labor Statitics, 2006). Recent expansion of various "high-tech" services may also open up greater possibilities for self-employment, since in many instances these services require relatively little physical capital (Steinmetz and Wright, 1989; Kuhn and Schuetze, 2001; United States Bureau of Labor Statitics, 2006).

There has also been a redistribution of the numbers of self-employed across various industries. The trade industry in the last two decardes has seen the growth of large and medium size enterprises (Steinmetz and Wright, 1989; Kuhn and Schuetze, 2001). Single-owner retail operations are not as profitable (and consequently not as numerous) as they used to be, primarily because they cannot compete with large supermarkets, franchises, and department stores. The service industries have remained steady, partly because many services are best performed on a personalized basis. Changes in the advanced industrial economies have made self- employment the more attractive option for individuals investigating new opportunities. Large fluctuations exist in the self-employment by smaller, younger firms, which tend to fail more frequently than larger firms (Evans and Leighton, 1989).

\section{CHARACTERISTICS OF SELF-EMPLOYED WOMEN}

In both Black and White racial groups, males are more likely than females to become self-employed (Kutscher, 1993; Boden, 1999a; Boden, 1999b; Kuhn and Schuetze, 2001). This is due to a number of factors. For example, women have not traditionally been regarded as business owners (Kutscher, 1993; Boden, 1999a; Boden, 1999b; Kuhn and Schuetze, 2001). Also, women perform a dual role in that they are usually responsible for domestic concerns, whether they are employed outside the home or not (Allen and Truman, 1993). In addition to being stagnated into perceived gender roles, women face additional obstacles at the beginning of and during the selfemployment process (Haddleston-Mattai, 1995; Smith-Hunter, 2006).

A steady increase in the number of females choosing to work for themselves is one of the more striking trends in the labor market in the last two decades (Devine, 1994; Kuhn and Schuetze, 2001; Caputo and Dolinsky, 1998). According to the Current Population Survey (CPS), the number of self-employed females aged 18 to 64 in the non-agricultural sector increased by 2.2 million (145 percent) between 1975 and 1990 (Bregger, 1996). This relatively large increase in self-employed females partially reflects an increase in the total number of employed females, but the more important factor is a large increase in the proportion of employed females choosing selfemployment.

Wharton (1989) suggests that self-employment has increased more for females who face increasing potential earnings in wage-and-salary employment, indicating that returns to skill were increasing by even more in self-employment. It was also noted that women with relatively low skill levels who faced declining real wages in wage-and-salary employment did not turn to self-employment in the same proportion as women with higher skill levels (Decarlo and Lyons, 1988). Caputo and Dolinsky (1998) showed that a husband's level of income can enable a woman to raise the necessary capital to start up her own business and to endure more easily the financial risk associated with being self-employed. This may be especially true in circumstances where the husband's income is the majority of household income, a finding consistent with those of other studies (Caputo and Dolinsky, 1998; Hundley, 2000).

Women may be interested in self-employment opportunities because of salary and position disadvantages in the labor market (Acker, 1990). Self-employment allows women to have more powerful positions, and to control their own lives. Positions that are mainly occupied by men in the mainstream labor market are more likely to be held by women in the self-employment sector, which many women see as a more attractive option.

Self-employed females are more likely than wage-and-salary females to be: (a) married with or without the spouse present (b) a parent, (c) covered by someone else's health insurance, (d) and working either a relatively small 
or relatively large number of hours (Hundley, 2000). These differences suggest that changes in the values attached to non-wage job characteristics and the composition of total compensation may have played an important role in producing a recent rise in female self-employment (Feagin and Imani, 1994; Hundley, 2000; Zapalske, 2006; Boden, 1999a).

The marital and parental statuses of self-employed women offer psychological, physical, and financial support. However, self-employed women face unfair obstacles when trying to obtain health care opportunities (Brown, 1996). A spouse who can provide health insurance coverage and thus encourage women into selfemployment sectors may be critical to these women (Hundley, 2000; Caputo and Dolinsky, 1998). Women can also receive financial assistance from a spouse, and unpaid labor from their children. Such additional support serves to encourage women into engaging in self-employment opportunities.

According to Devine(1994), statistics have shown that, on average, self-employed women tend to be older than their wage-and-salary counterparts. Devine further states that self-employment rates for women ages 45-54 and 55-64 increased substantially after 1975 (Devine, 1994). Women aged 65 and older maintained the highest selfemployment rate throughout the 1975-1990 period (Devine, 1994).

Self-employed women have more years of education completed, on average, than do their wage-and-salary counterparts and are increasingly more likely to have at least four years of college (Wharton, 1989). In addition, mean education levels for self-employed men are consistently higher than that of self-employed women (Wharton, 1989). However, the difference in education levels, between self-employed women and wage-and-salary women, is smaller than the difference between self-employed men and self-employed women (Decarlo and Lyons, 1988)

A striking contrast exists between self-employed women, self-employed men, and wage-and-salary women, in regard to the number of full time hours worked. Between 1975 and 1990, the number of self-employed women working full time increased by 33.5 percent, as compared to their wage-and-salary counterparts, who showed a 52.7 percent increase (Devine, 1994). The numbers of self-employed men fluctuated between 70 percent and 74 percent during the same period (Devine, 1994).

Institutions, such as banks and government agencies, that assist self-employed women with their businesses tend to favor older women with more workplace experience in management positions (Allen and Truman, 1993; Decarlo and Lyons, 1988; Smith-Hunter, 2006). Such agencies also favor women with higher educational levels, because they are seen as more likely to maintain viable businesses (Devine, 1994; Carroll and Mosakowski, 1987; Moore and Buttner, 1987; Smith-Hunter, 2003).

Self-employed women are more likely to be in sales and service occupations than in wage and salary jobs (Devine, 1994). In the last decades however, self-employed women have moved out of the personal services sectors, such as the beauty industry, and into business, repair industries, and the retail trade (Devine 1994; Smith-Hunter, 2006).

Personal and retail service areas, categorized mainly by the nature of the products and service offered, are the original and traditional sectors for self-employed women, and represen an extension of the gender-based roles women have occupied in the home (Roos, 1990). The revolutionary impact of the Women's Movement has resulted in women occupying previously nontraditional roles in the mainstream labor market. This trend has extended to the self-employment sectors, with women having the highest employment growth numbers in construction, wholesaling, and communication (Brown, 1996; United States Census Bureau, 2000; Smith-Hunter. 2006).

Self-employed women are consistently more likely to be married and with their spouse present than their wage-and-salary counterparts (Boden, 1999a; Boden, 1999b; Hundley, 2000). Specifically, married spouse-present women represent about 75 percent of all self-employed women. Those who are not married with the spouse present, are more likely to have been married previously (Hundley, 2000). 
Other differences in the self-employment sector include gender composition and inequality, and in engineering, mining, and construction industries (United States Census Bureau, 2000). Women seeking to establish their own businesses have difficulty securing financial assistance in these industries, which may account for their low participatory rates (Wharton, 1989; Smith-Hunter, 2006). In addition, the earnings gap between men and women was largest for the self-employed, with men earning almost three times more than their female counterparts (Coleman and Pencavel, 1993). This gap can be partly explained by the industries that numbers of women are concentrated in-industries that are less lucrative, such as personal services and the retail trade (Smith-Hunter, 2006).

\section{CHARACTERISTICS OF SELF-EMPLOYED AFRICAN AMERICANS AND OTHER MINORITIES}

In 1995, the much lower self-employment entry rates among Blacks (2.43 percent) relative to non-minority males (9.71 percent), clearly reflect in part, their lower wealth holdings and weaker educational backgrounds (Bates, 1995). More recent statistics indicate that the number of Blacks in relation to the total number of self-employed individuals stands at 5.60 percent (United States Bureau of Labor Statistics, 2006). Overall, studies indicate lower rates of business formation for Blacks, after controlling for levels of wealth, education, and demographic differences (Fratoe, 1991; Feagin and Imani, 1994; Fairlie and Meyer, 2000). This latter factor may at first indicate that Blacks and other minority groups face barriers to business entry that non-minorities do not face, or that they have less preference for business ownership than do non-minorities (Fratoe, 1991; Feagin and Imani, 1994; Fairlie and Meyer, 2000).

Obtaining capital is one of the greatest obstacles African Americans encounter in pursuing selfemployment opportunities. Blacks and other minority groups are the most likely to suffer from a capital shortage when entering the self-employment sector (Scott, 1983, Van Auken and Horton, 1994; Hout and Rosen, 2000). They are also more likely to be refused credit for start-up, expansion, or rejuvenation purposes for their businesses (Bates and Osborne, 1979; Bates, 1990; Hout and Rosen, 2000). This is tied to the institutional barriers (Scott, 1983) that Blacks and other minority groups face in the financial sector.

The Small Business Administration (SBA) offers alternative loans for Blacks but there are problems. (Bates and Osborne. 1979; Bates, 1995). The loans are difficult for Blacks to obtain because of the SBA's credit and collateral restrictions that limit the position of Black business owners who are assessed by collateral, as opposed to White business owners who are assessed mainly by cash flow ability (Bates and Osborne, 1979; Bates, 1995). These factors undermine and limit the opportunities and potential for Black business owners.

Certain distinctions are made for minority business owners, such as education, capital, and other areas that must be addressed in order for them to be viable members of this labor sector. Members of minority groups are statistically more likely than others to lack education and self-employment training. Non-minority groups are more likely to be trained in family-owned businesses, or in the mainstream employment sector regarding self-employment opportunities (Hout and Rosen, 2000; Fairlie and Meyer, 2000).

According to Characteristics of Business Owners (CBO), Black business owners have the lowest rate (25 percent) of completing four or more years of college, compared to White business owners (Fratoe, 1988; SmithHunter, 2003). Black business owners were also less likely to have worked two or more years in a managerial capacity, and more likely to have no managerial experience (Bates, 1990; 1991; Smith-Hunter, 2003). In addition, Blacks were the least likely of all groups to have already owned a business, and thus the least likely to have acquired entrepreneurial experience through such means (Bates, 1996; Feagin and Imani, 1994).

The lack of training and education of self-employed Blacks is due to three key factors. First, sociodemographic analyses (Woodson, 1988; Horton, 1988) indicate that Blacks are less likely to know someone who is self-employed, or to have parents who are self-employed. Second, Blacks in the mainstream labor market are less likely to be given responsibilities, or to obtain management positions (Sullivan and McCracken, 1988; Inman, 2001). Finally, Blacks are less likely than Whites to attend or complete college (Glazer, 1986; Bates, 1991). These factors result in Blacks being less exposed to the necessary training and experience needed for the self-employment 
sector. Such lack of training can eventually negatively impact those Blacks who do enter the self-employment sector, resulting in struggling business and high mortality rates for Black businesses (Boyd, 1991; Smith-Hunter, 2003).

Securing financial assistance for the start up and continuation of their businesses is a critical area of concern for Black and other minority businesses owners. Most minority-owned businesses receive little or no capital from organized financial markets at the point of start up (Bates, 1991). Commercial bank loans are the most common form of debt financing; other sources include family, the former owner of the business, friends, and governmental agencies. Another interesting factor for self-employed minorities is that most begin their businesses with less than $\$ 5000$, most reporting that they borrowed no initial capital to start their businesses (Fratoe, 1988, Bates, 1991). It is widely believed that the minority business sector suffers from the limited financial resources of the minority community and from the institutional barriers minorities face in the credit market (Scott, 1983; SmithHunter, 2006).

In recent decades, minority business owners have shifted away from traditional fields, such as personal services, favoring skill-intensive services and wholesaling (Smith-Hunter, 2006). The most rapidly growing lines of minority self-employment are: business services, finance, insurance, real estate, wholesaling, transportation, and communication. Although previously popular sectors, such as personal services and retail, continue to have high entry rates for Blacks, the retention and exit rates continue to be unfavorable, leading to a stagnant development in such areas (Smith and Moore, 1985; Smith-Hunter, 2006).

There have been many reasons brought forward for the exclusion of Black and other minority groups from certain industries. There is Feagin and Imani's (1994) contention of the racial barriers that self-employed African Americans experience in the construction industry, which look at them being omitted from key social and business networks that are a must in the industry for obtaining lucrative contracts and remaining viable. In addition, Bates (1986) and Sullivan and McCracken (1988) demonstrated that Blacks continue to be excluded from some industries, such as manufacturing, real estate, communication, and insurance which require significant capital to start and operate in .

According to Feagin and Imani (1994), most business owners are married. Black business owners have a high marriage rate of 70 percent, however, they are less likely to be married than their Asian (82 percent), Hispanic (80 percent), or non-minority (83 percent) counterparts. Minority business owners are also more likely to be live in communities composed mostly of their minority group. This may explain why their businesses have lower survival rates, since minority communities are often at the lower end of the economic strata, and are thus less likely to purchase goods at a rate and price that would serve to sustain such businesses.

\section{CHARACTERISTICS OF SELF-EMPLOYED AFRICAN AMERICAN AND OTHER MINORITY WOMEN}

Black women occupy a uniquely disadvantaged position in the workplace (Haddleston-Mattai, 1995). Their gender and racial status place them in a lower position than White men - the dominant group - Black men, and White women (Bell, 1990). This lower position is also evident in the self-employment sector, where Black women are less likely than their White or male counterparts to be given certain opportunities (Decarlo and Lyons, 1978; Brown, 1996). While Black women experience the same disadvantages that White women and Black men receive, the impact is more severe because of their double-disadvantaged position (Haddleston-Mattai, 1995).

One main reason for Black and other minority women choosing self-employment is that they are not given adequate opportunities and rewards in the mainstream labor market (Brown, 1996; Smith-Hunter, 2006). Selfemployment thus represents a viable option for realizing one's self worth. Black women see self-employment as an alternative to the mainstream labor market, both in terms of the income potential and the opportunity for personal growth.

A few studies indicate that banks often do not apply affirmative action measures with self-employed Black women (Allen and Truman, 1993;Smith-Hunter, 2006). Black women are thus the least likely group to obtain 
traditional bank loans, and more likely to save and invest personal funds in starting their businesses at a later age (Allen and Truman, 1993). The negative stereotype of Black women as lacking experience and self-employment training results in decreased likelihood of offered partnership opportunities with other entrepreneurs (Bell, 1990; Smith-Hunter, 2006).

Historically, the most explosive growth for Black-woman-owned businesses are in the following industries: construction, wholesale trade, transportation, communication, agriculture, and manufacturing (Brown, 1996; SmithHunter, 2006, Kearney, 2006). Black women business owners are more likely to be older than their counterparts, typically starting their businesses at a later age (Smith-Hunter, 2006). They are also less likely to be married than their counterparts. Black women are less likely to have graduated from college. They are more likely to have started their businesses alone than with a partner (Decarlo and Lyons, 1988).

The last three decades have seen the movement of Black women into non-traditional areas of employment because of affirmative action (Fielden, Davidson, Gale and Davey, 2001. This movement also impacts the selfemployment sector, where Black women are expanding their businesses into nontraditional areas. Black women continue to battle the perception that they are not successful and viable business owners.

\section{DISCUSSION AND RECOMMENDATIONS FOR FUTURE RESEARCH}

A review of literature reveals that, in general, underrepresented groups occupy a lower position in the selfemployment sector in comparison to what they experience in the mainstream labor market. Black women are in a unique position of having a "double- disadvantaged" position, compared to their White and male counterparts.

The self-employment sector creates a large share of new jobs in the economy that are thus an important source of innovation and have an important effect on political decisions in the United States (Fairlie and Meyer, 2000). Many academics and policymakers view self-employment as a route out of the labor market (Fairlie and Meyer, 2000). The institutional environment for the self-employed differs in important ways from that of wage/salary workers. The self-employed are not subject to the usual labor contracts and their consequent incentives, and they either do not receive, or purchase for themselves, fringe benefits usually provided by employers, such as health insurance and pensions (Fairlie and Meyer, 2000). The self-employed have a different return to education, will have a different age-earning profile, and have more variability in hours worked, compared to their wage/salary workers (Fairlie and Meyer, 2000). Finally, the self-employed are often singled out in the formation of public policy. They face different income tax treatment and are frequently excluded from social insurance programs (Fairlie and Meyer, 2000).

The lack of precise data on Black self-employed women is evidence that despite recent impressive gains, they are still fighting for recognition. Such statistical and empirical data are extremely important as a measure of advancement for self-employed Black women, by providing a source of data for interested agencies and institutions. 
Table 1-Self-Employed Workers: All Races

\begin{tabular}{|c|c|c|c|}
\hline Self- Employed Workers & Employed Full Time & Employed Part Time & Unemployed \\
\hline $\begin{array}{l}\text { Agriculture. and Related Industries: } \\
\text { Men } \\
\text { Women } \\
\text { TOTAL }\end{array}$ & $\begin{array}{l}664 \\
237 \\
901 \\
\end{array}$ & $\begin{array}{l}129 \\
116 \\
245 \\
\end{array}$ & $\begin{array}{c}8 \\
1 \\
10 \\
\end{array}$ \\
\hline $\begin{array}{l}\text { Non-agriculture Industries: } \\
\text { Men } \\
\text { Women } \\
\text { TOTAL }\end{array}$ & $\begin{array}{l}6,004 \\
3,681 \\
9,685 \\
\end{array}$ & $\begin{array}{l}1,037 \\
1,471 \\
2,507 \\
\end{array}$ & $\begin{array}{c}191 \\
91 \\
282 \\
\end{array}$ \\
\hline $\begin{array}{l}\text { Agriculture and related-Incorporated: } \\
\text { Men } \\
\text { Women } \\
\text { TOTAL }\end{array}$ & $\begin{array}{c}120 \\
45 \\
165 \\
\end{array}$ & $\begin{array}{l}13 \\
19 \\
32 \\
\end{array}$ & $\begin{array}{l}0 \\
0 \\
0 \\
\end{array}$ \\
\hline $\begin{array}{l}\text { Nonagriculture-Incorporated: } \\
\text { Men } \\
\text { Women } \\
\text { TOTAL }\end{array}$ & $\begin{array}{l}3,869 \\
1,465 \\
5,334\end{array}$ & $\begin{array}{l}329 \\
427 \\
756\end{array}$ & $\begin{array}{l}25 \\
14 \\
39\end{array}$ \\
\hline
\end{tabular}

Source: 2006 Current Population Survey, United States Bureau of Labor Statistics, Table 16 (Numbers in Thousands)

Note: Total columns do not always sum exactly due to rounding errors.

Table 2-Self-Employed Workers: Blacks

\begin{tabular}{|c|c|c|c|}
\hline Self- Employed Workers & Employed Full Time & Employed Part Time & Unemployed \\
\hline $\begin{array}{l}\text { Agriculture and Related Industries: } \\
\text { Men } \\
\text { Women } \\
\text { TOTAL }\end{array}$ & $\begin{array}{l}6 \\
1 \\
6\end{array}$ & $\begin{array}{l}1 \\
0 \\
1\end{array}$ & $\begin{array}{l}2 \\
0 \\
2\end{array}$ \\
\hline $\begin{array}{l}\text { Non-agriculture Industries: } \\
\text { Men } \\
\text { Women } \\
\text { TOTAL }\end{array}$ & $\begin{array}{l}387 \\
249 \\
635 \\
\end{array}$ & $\begin{array}{r}79 \\
68 \\
147 \\
\end{array}$ & $\begin{array}{l}36 \\
19 \\
55 \\
\end{array}$ \\
\hline $\begin{array}{l}\text { Agriculture and Related Incorporated: } \\
\text { Men } \\
\text { Women } \\
\text { TOTAL }\end{array}$ & $\begin{array}{l}2 \\
0 \\
2\end{array}$ & $\begin{array}{l}1 \\
0 \\
1\end{array}$ & $\begin{array}{l}0 \\
0 \\
0\end{array}$ \\
\hline $\begin{array}{l}\text { Nonagriculture-Incorporated: } \\
\text { Men } \\
\text { Women } \\
\text { TOTAL }\end{array}$ & $\begin{array}{c}172 \\
69 \\
241\end{array}$ & $\begin{array}{c}14 \\
9 \\
23\end{array}$ & $\begin{array}{l}4 \\
3 \\
6\end{array}$ \\
\hline
\end{tabular}

Source: 2006 Current Population Survey, United States Bureau of Labor Statistics, Table 16 (Numbers in Thousands).

Note: Total columns do not always sum exactly due to rounding errors. 
Table 3-Self-Employed Workers: Asians

\begin{tabular}{|c|c|c|c|}
\hline Self- Employed Workers & Employed Full Time & Employed Part Time & Unemployed \\
\hline $\begin{array}{l}\text { Agriculture and Related Industries: } \\
\text { Men } \\
\text { Women } \\
\text { TOTAL }\end{array}$ & $\begin{array}{c}8 \\
3 \\
10\end{array}$ & $\begin{array}{l}0 \\
0 \\
0\end{array}$ & $\begin{array}{l}2 \\
0 \\
2\end{array}$ \\
\hline $\begin{array}{l}\text { Non-agriculture Industries: } \\
\text { Men } \\
\text { Women } \\
\text { TOTAL }\end{array}$ & $\begin{array}{l}283 \\
195 \\
478\end{array}$ & $\begin{array}{l}31 \\
53 \\
83\end{array}$ & $\begin{array}{l}6 \\
2 \\
8\end{array}$ \\
\hline $\begin{array}{l}\text { Agriculture and Related Incorporated: } \\
\text { Men } \\
\text { Women } \\
\text { TOTAL }\end{array}$ & $\begin{array}{l}1 \\
0 \\
1\end{array}$ & $\begin{array}{l}0 \\
0 \\
0\end{array}$ & $\begin{array}{l}0 \\
0 \\
0\end{array}$ \\
\hline $\begin{array}{l}\text { Nonagriculture.-Incorporated: } \\
\text { Men } \\
\text { Women } \\
\text { TOTAL }\end{array}$ & $\begin{array}{l}207 \\
116 \\
323\end{array}$ & $\begin{array}{l}10 \\
30 \\
40\end{array}$ & $\begin{array}{l}1 \\
0 \\
1\end{array}$ \\
\hline
\end{tabular}

Source: 2006 Current Population Survey, United States Bureau of Labor Statistics, Table 16 (Numbers in Thousands). Note: Total columns do not always sum exactly, due to rounding errors.

Table 4-Self-Employed Workers: Hispanics

\begin{tabular}{|c|c|c|c|}
\hline Self-Employed Workers & Employed Full Time & Employed Part Time & Unemployed \\
\hline $\begin{array}{l}\text { Agriculture and Related Industries: } \\
\text { Men } \\
\text { Women } \\
\text { TOTAL }\end{array}$ & $\begin{array}{c}14 \\
4 \\
18\end{array}$ & $\begin{array}{l}3 \\
2 \\
5\end{array}$ & $\begin{array}{l}1 \\
0 \\
2\end{array}$ \\
\hline $\begin{array}{l}\text { Non-agriculture Industries: } \\
\text { Men } \\
\text { Women } \\
\text { TOTAL }\end{array}$ & $\begin{array}{c}783 \\
347 \\
1,130\end{array}$ & $\begin{array}{l}108 \\
120 \\
229\end{array}$ & $\begin{array}{l}32 \\
12 \\
43\end{array}$ \\
\hline $\begin{array}{l}\text { Agriculture and Related Incorporated: } \\
\text { Men } \\
\text { Women } \\
\text { TOTAL }\end{array}$ & $\begin{array}{l}3 \\
0 \\
4\end{array}$ & $\begin{array}{l}0 \\
0 \\
0\end{array}$ & $\begin{array}{l}0 \\
0 \\
0\end{array}$ \\
\hline $\begin{array}{l}\text { Nonagriculture-Incorporated: } \\
\text { Men } \\
\text { Women } \\
\text { TOTAL }\end{array}$ & $\begin{array}{c}265 \\
94 \\
359\end{array}$ & $\begin{array}{l}19 \\
23 \\
41\end{array}$ & $\begin{array}{l}2 \\
1 \\
2\end{array}$ \\
\hline
\end{tabular}

Source: 2006 Current Population Survey, United States Bureau of Labor Statistics, Table 16 (Numbers in Thousands).

Note: Total columns do not always sum exactly due to rounding errors.

\section{AUTHOR INFORMATION}

Andrea E. Smith-Hunter is an Associate Professor at Siena College in Loudonville, New York. She holds a Ph.D. in Organizational Studies from the University at Albany - State University of New York. Her research interests include entrepreneurship across racial, ethnic, gender and economic lines. She has published journal articles in the Journal of Business and Entrepreneurship, the Journal of International Business and Entrepreneurship, Women in Management Review and the Journal of Business and Economic Research, among others. Her first book, Diversity and Entrepreneurship: Analyzing Successful Women Entrepreneurs, was published in 2003 and her second book, Women Entrepreneurship Across Racial Lines: Issues of Human Capital, Financial Capital and Network Structures was published in 2006. 


\section{REFERENCES}

1. Acker, Joan. 1990. Hierachies, jobs, bodies: A theory of gendered organizations. Gender and Society, volume 4, pages 139-158.

2. Allen, S. and Truman, C. 1993. Women in Business: Perspectives on Women Entrepreneurs. Routledge Publishers, London.

3. Arenius, P. and Kovalainen, A. 2006. Similarities and differences across the factors associated with women's self-employment preferences in Nordic countries. International Small Business Journal, volume 24, number 1, pages 31-59.

4. Bates, Timothy. 1995. Self-Employment Entry Across Industry Groups. Journal of Business Venturing. Volume 10, pages 143-156.

5. Bates, Timothy. 1986. Characteristics of Minorities who are Entering Self-Employment. The Review of Black Political Economy. Fall, pages 31-49.

6. Bates, Timothy. 1990. Entrepreneur Human Capital Inputs and Small Business Longevity. The Review of Economics and Statistics, volume 22, number 4, pages

7. 551-559.

8. Bates, Timothy. 1991. Commercial Bank Financing of White and Black Owned Small Business Start-ups. Quarterly Review of Economics and Business, volume 31, number 1, pages 64-80.

9. Bates, T. and Osborne, A. 1979. The Perverse Effects of SBA Loans to Minority Wholesalers. Urban Affairs Quarterly, volume 15, number 1. Pages 87-98.

10. Bell, Ella L. 1990. The bicultural life experience of career- oriented black women. Journal of Organizational Behavior, volume11, pages 459-477.

11. Blau, David. 1987. A Time-Series Analysis of Self-Employment in the United States. Journal of Political Economy. Volume 95, number 31. Pages 445-467.

12. Boden, R. 1999a. Flexible working hours, family responsibilities, and female self-employment: Gender differences in self-employment selection. American Journal of Economics and Sociology, volume 58, number 1, pages 71-83.

13. Boden, R. 1999b. Gender inequality in wage earnings and female self-employment selection. Journal of Socio-Economics, volume 28, number 3, pages 351-365.

14. Bowen, D. and Hisrich, R. 1986. The female entrepreneur: A career development perspective. The Academy of Management Review, volume 11, number 2, pages 393-407.

15. Boyd, Robert. 1991. Black Entrepreneurship In 52 Metropolitan Areas. Social Science Review, volume 75 , pages $158-163$.

16. Bregger, John. 1963. Self-employment in the United States, 1948-1962. Monthly Labor Review, January. pages 37-43.

17. Bregger, John. 1996. Measuring Self-Employment in the United States. Monthly Labor Review, January/February, pages 3-9.

18. Brown, Carolyn. 1996. They've Got The Power. Black Enterprise, August, pages 63-66.

19. Bygrave, W. and C. Hofer. 1991. Theorizing about entrepreneurship. Entrepreneurship, Theory and Practice, volume 16, number 2, pages 13-22.

20. Caputo, R. and Dolinsky, A. 1998. Women's choice to pursue self-employment: The role of financial and human capital of household members. Journal of Small Business Management, volume 36 , number 3, pages 8-17.

21. Carroll, G. \& Mosakowshi, E. 1987. The Career Dynamic of Self- Employment. Administrative Science Quarterly, volume 32, pages 570-589.

22. Coleman, M. \& Pencavel. 1993. Trends in Market Work Behavior of Women Since 1940. Industrial and Labor Relations Review, volume 46, number 4, pages 653-676.

23. Collins, Sharon. 1993. Blacks on the bubble: The vulnerability of black executives in white corporations. Sociological Quarterly, volume 34, pages 429-447.

24. Decarlo, F and Lyons, P. 1988. A Comparison of Selected Personal Characteristics of Minority and NonMinority Female Entrepreneurs. The Successful Female Entrepreneur: Journal of Small Business Management, volume 17, pages 22 -29. 
25. Devine, Theresa. 1994. Characteristics of the Self-Employed Women in the United States. Monthly Labor Review, volume 117, pages 20-34.

26. Devine, Theresa. 1994. Changes in Wage-and-Salary Returns to Skill and the Recent Rise in Female Self-Employment. Economic Issues For Work and Family. Volume 84, Number 2. Pages 108-113.

27. Evans, D. \& Leighton, L. 1989. Some Empirical Aspects of Entrepreneurship. The American Economic Review. Volume 79, number 3, pages 519-535.

28. England, Paula and Lori McCreary. 1987. Gender inequality in paid employment. In B. Hess and M. Ferree, eds. Analyzing Gender. Newbury Park, California: Sage Publications.

29. Fairlie, R. and Meyer, B. 2000. Trends in Self-employment among white and black men during the Twentieth Century. The Journal of Human Resources, volume 35, number 4, pages 643-669.

30. Feagin, J. and Imani, N. 1994. Racial Barriers to African American Entrepreneurship: An Exploratory Study. Social Problems, volume 41, number 4, pages 562-585.

31. Fielden, S., Davidson, M., Gale, A. and C. Davey. 2001. Women, equality and construction. The Journal of Management, Volume 20, 4, pages 293-305.

32. Fratoe, Frank. 1988. Social Capital of Black Business Owners. The Review of Black Political Economy, Spring, pages 33-50.

33. Gartner, W. 1988. A conceptual framework for describing the phenomenon of new venture creation. Academy of Management Review, volume 10, number 4, pages 696-706.

34. Glazer, Nathan. 1986. Education and Training Programs and Poverty. In S. Danziger and D. H. Weinberg. Fighting Poverty: What Works and What Doesn't. Cambridge, Massachusetts. Harvard University Press.

35. Godbout, T. 1993. Employment Change and Sectoral Distribution in 10 Countries, 1970-1990. Monthly Labor Review, October. Pages 3- 20.

36. Haddleston-Mattai, Barbara. 1995. The Black female academician and the 'superwoman syndrome. Race, Gender and Class 3: 49-64.

37. Horton, Hayward. 1988. Occupational Differentiation and Black Entrepreneurship: A Sociodemographic Analysis. National Journal of Sociology. Fall. Pages 187-201.

38. Hout, M. and Rosen, H. 2000. Self-employment, family background and race. The Journal of Human Resources, volume 35, number 4, pages 670-692.

39. Hundley, G. 2000. Male/female earnings differences in self-employment: The effects of marriage, children and the household division of labor. Industrial and Labor Relations Review, volume 14, number 1, pages 95-114.

40. Inman, K. 2000. Women's Resources in Business Start-Up: A Study of Black and White Women Entrepreneurs. New York and London: Garland Publishing.

41. Kearney, M. 2006. Intergenerational mobility for women and minorities in the United States. The Future of Children, Volume 16, number 2, pages 37-53.

42. Kuhn, P. and Schuetze, H. 2001. Self-employment dynamics and self-employment trends: A study of Canadian men and women, 1982-1998. The Canadian Journal of Economics, volume 34, number 3, pages 760-784.

43. Kutscher, Ronald. 1993. Historical Trends, 1950-1992 and Current Uncertainties. Monthly Labor Review, November, pages 3-10.

44. Linder, M. \& Norton, L. 1987. The Employee-as-Contractor Dodge. Philadelphia Enquirer, June 15

45. Lucas, Robert. 1978. On The Size Distribution of Business Firms. The Bell Journal of Economics. Volume 9. Pages 508-523.

46. Marlow, S. and Patton, D. 2005. All credit to men? Entrepreneurship, finance and gender. Entrepreneurship, Theory and Practice, volume 29, number 6, pages 717-735.

47. Moore, D. and Buttner, H. 1997. Women Entrepreneurs: Moving Beyond The Glass Ceiling. Thousand Oaks, CA: Sage Publications.

48. Reskin and Roos. 1990. Job Queues, Gender Queues: Explaining women's inroads into male occupations. Temple University Press. Philadelphia, United States.

49. Sanders, J. $8 r$ Nee, V. 1996. Immigrant Self-Employment: The Family as Social Capital and the Value of Human Capital. American Sociological Review, volume 61, pages 231-249. 
50. Scott, William. 1983. Financial Performance of Minority Versus Nonminority-Owned Businesses.

Journal of Small Business Management. January. Pages 42-48.

51. Sexton, D. and R. Ssmilor. 1986. The Art and Science of Entrepreneurship. Cambridge, MA:Ballinger.

52. Smith, A. and Moore, J. 1985. East-West Differences in Black Economic Development. Journal of Black Studies, volume 16, number 2, pages 131-154.

53. Smith-Hunter, A. 2006. Women Entrepreneurs Across Racial Lines: Issues of Human Capital, Financial Capital and Network Structures. Edward Elgar Publishing, London.

54. Smith-Hunter, A. 2003. Diversity and Entrepreneurship: Analyzing Successful Women Entrepreneurs. Lanham, MD: University Press of America.

55. Steinmetz, G. \& Wright, E. 1989. The Fall and Rise of the Petty Bourgeoise: Changing Patterns of SelfEmployment in the Postwar United States. American Journal of Sociology, volume 94, number 5, pages 973-1018.

56. Sullivan, T. and McCracken, S. 1988. Black Entrepreneurs: Patterns and Rates of Return to SelfEmployment. National Journal of Sociology. fall, pages 167-185.

57. Van Auken, H. and Horton, H. 1994. Financing Patterns of Minority-Owned Small Business. Journal Of Small Business Strategy. pages 31-43.

58. Wharton, Amy. 1989. Gender Segregation in Private Sector, Public Sector, and Self-employed Occupations, 1950-1981. Social Science Quarterly. volume 70, number 4, pages 923-939.

59. Woodson, Robert L. 1988. Black America's legacy of entrepreneurship. National Journal of Sociology, volume 2, pages 204-224.

\section{NOTES}


NOTES 